2020, Volume 10, International Conference Globalization, Innovation and Development. Trends and Prospects (G.I.D.T.P.), pages: 180-190 | https://doi.org/10.18662/lumproc/gidtp2018/21

\section{Trends in Women Education and Training in Romania}

Andreea Violeta
ANDREIANA ${ }^{1}$,
Laura MARCU* $^{2}$

${ }^{1}$ Valahia University of Targoviste, Targoviste, Romania, andreea.vivi@yahoo.com

2 Valahia University of Targoviste, Targoviste, Romania, laura_marcu_uvt@yahoo.fr

Corresponding author
Abstract: Among EU Member States, Romania has one of the highest rates of early leavers from education. Meanwhile, adult training is quite low compared to the European average. These factors affect young people's ability to integrate both social and labour market. In our paper, we analyze the participation of Romanian female population in the educational process. For this purpose we use descriptive statistics to highlight the evolution of the participation in education of the female population, the gap that exists between men and women in terms of early school leave, tertiary studies fulfilled and adult learning.

Keywords: adult learning; education; gender gap; training; Romania; women.

How to cite: Andreiana, A.V., \& Marcu, L. (2020). Trends in Women Education and Training in Romania. In I. Panagoret, \& G. Gorghiu (vol. ed.), Lumen Proceedings: Vol. 10. International Conference Globalization, Innovation and Development. Trends and Prospects (G.I.D.T.P.) (pp. 180-190). Iasi, Romania: LUMEN Publishing House.

https://doi.org/10.18662/lumproc/gidtp2018/21 


\section{Introduction}

In light of the problems caused by the economic crisis began in 2008, EU Member States have adopted the Strategy Europe 2020. By this strategy, the EU has chosen priorities that will aim to restore economic growth on the continent: the support of innovation, sustainable development and economic inclusion, social and territorial cohesion. Education is considered a main objective, achieving it is a guarantee of achieving the priorities assumed. More specifically, in the Europe 2020, MS assumed reducing school dropout rates below 10\%, an increase in the level of education for the younger generation so that at least $40 \%$ of people aged between 30 and 34 years have university studies and a rate of at least 15\% of people between 25 and 64 years participating in lifelong learning.

Interest in education is justified by the influence it exerts both on growth and on the level of inclusion. Meanwhile, in Europe is expected to increase the supply of jobs requiring high skills and a decrease in low-skilled jobs [2]. In this context, both education and training are the only ones that can provide an adequate response to the need for skills in the labour market. Finally, the EU wants to match the situation of developed countries, where the education level of the population is higher than in Europe. For example, the percentage of people between 30-34 years with higher education was already, when adopting the strategy, $40 \%$ in US and 50\% in Japan, compared to only $31 \%$ in the EU [2]. Among the solutions adopted to meet the objectives set at European level, there are two initiatives of the EC specifically targeting educational dimension ("Youth on the Move" and "Agenda for new skills and jobs") who establish lines of action both at European and national level [1].

\section{Methodology}

\subsection{Problem statement}

If EU school dropout rate for young people aged between 18 to 24 years had a constant downward trend, from $14.9 \%$ in 2007 to $13.9 \%$ in 2010 , when Europe 2020 was adopted and to $10.6 \%$ in 2017, in Romania the situation in the 10 years since accession has not improved. The rate of premature abandonment of studies has often ebbed (17.3\% in 2007, 19.3\% in $2010,17.3 \%$ in $2013,19.1 \%$ in $2015 \ldots 18.1 \%$ in 2017 ), but the gap with the European average has increased. Thus, Romania is among the last countries in the EU, higher dropout rates were observed in 2017 only in 
Malta (18.6\%) and Spain (18.3\%). Note that the target assumed by Romania is at a level of $11.3 \%$ while in Spain at $15 \%$ and in Malta at $10 \%$. As a comparison, the highest rates are recorded, in 2017, in Iceland (17.8\%), Italy (14\%), Portugal (12.6\%), Bulgaria (12.7\%) and Hungary (12.5\%) [3].

Instead, paths for young people between 30 and 34 years who have completed higher education in Romania was positive in the 10 years since accession, from $13.9 \%$ in 2007 , to $20.3 \%$ in 2011 and $26.3 \%$ in 2017 . Thus, the increase rate was $4.4 \%$ in the period $2007-2010$ and $8 \%$ between 2017 and 2010, an evolution more dynamic than the European average. Note that Romania has assumed a target of $26.7 \%$ by 2020 , so it's pretty close to achieving it. Analyzing the evolution of the two indicators we observe a paradox situation: the dropout rate among young people increase, but also increases the rate of young people who completed university studies.

According to a World Bank study in 2011, developing higher education in Romania was mainly achieved in the social sciences, while engineering and scientific fields decreased in relative terms. As a result, in 2008 Romania had the highest proportion of socio-economic sciences graduates in the EU. Regarding the distribution of the two sexes, in 2010 women accounted for over $60 \%$ of graduates in the fields of "medicine", "humanities and arts", ,,social sciences, business and law" and over $50 \%$ of graduates "real sciences". Instead, men accounted for more than half of graduates in the fields of "services", "agriculture", "engineering, manufacturing and construction"[5].

\subsection{Aims of the research}

Our analysis aims to highlight the situation in Romania in terms of education and training differences between men and women and if there are major gaps compared to the situation in EU. We have studied the difference between the two genders in terms of indicators set by Europe 2020 (the dropout rate for people between 18 and 24 years, the rate of graduates aged between 30 and 34 years and the rate for participating in adult learning). We also want to broaden the analysis to all ages, so we study the difference between the sexes in terms of graduation rate at all levels of study for population between 15 and 64 years, while the rate of participation in continuous training refers to the population aged between 25 and 64 years.

\subsection{Research Methods}

Our study is empirical, based on analysis of primary statistical data during 2007-2017 to identify indicators of education and calculating discrepancies between genders. In addition, data will be complemented by 
information obtained from the literature review or the reports which presents the situation of EU member countries and reports that address synthetic main features of Member States and directions for future action.

\section{Findings}

\subsection{The Dropout Rate among Women in Romania}

Figure no. 1 shows the evolution of dropout rates of the two sexes for people between 18 and 24 years: the columns indicate the dropout rate for men and women for the period 2007-2017, and the broken line indicates the difference between the sexes. The gender gap is calculated as difference between the female dropout rate and male dropout rate. Thus, it observes that abandonment was higher among girls in 2007-2009, among boys during 2008-2015 and again among girls in the last two years (2016-2017).

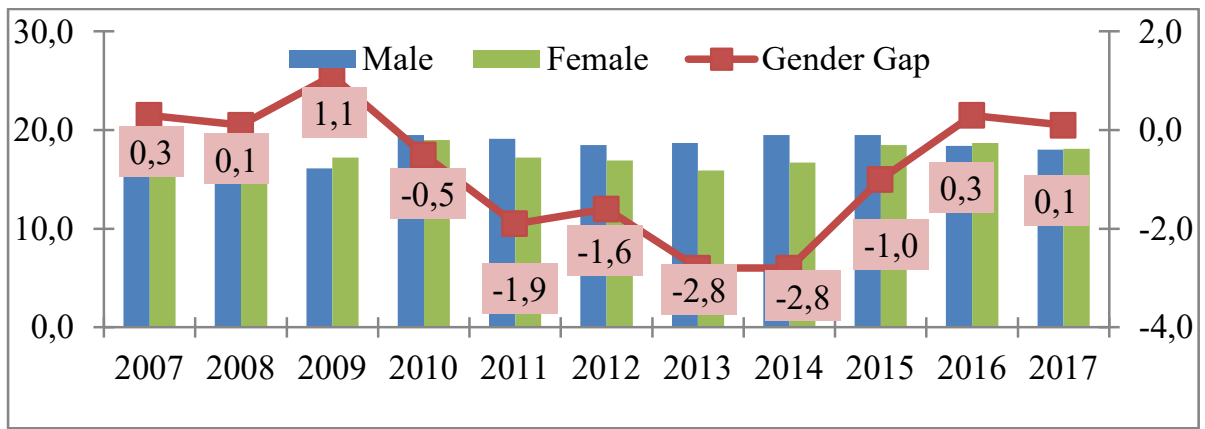

Source: authors using Eurostat data.

Figure no. 1. Gender gap in early leave from education, Romanian people between 18 and 24 years, $2007-2017$ (\%)

Note that the EU average dropout rate for the population between 18 and 24 years was higher than in Romania among the men. For example, in 2010, the dropout rate to UE28 level was $11.9 \%$ among girls and $15.8 \%$ among boys, the gap calculated by the formula used in figure no. 1 are $11.9 \%-15.8 \%=-3.9 \%$. Figures for 2017 are, in UE28, 8.9\% dropout rate for girls and $12.1 \%$ dropout rate for boys, respectively a difference that is not very different from 2010: $8.9 \%-12.1 \%=-3.2 \%$.

\subsection{The Education Level of Female Population in Romania}

For the age group 30-34 years, higher graduation rate is higher among girls than boys. The figure no. 2 highlight by broken line the gap 
between the two genders, calculated as the difference between graduation rates of girls and boys. For 2017, the graduation rate for girls was $28.9 \%$, compared with a completion rate of boys of only $23.9 \%$, i.e. a difference of $5 \%$. Basically, throughout the period 2007-2017 the gap was positive in favour of girls.

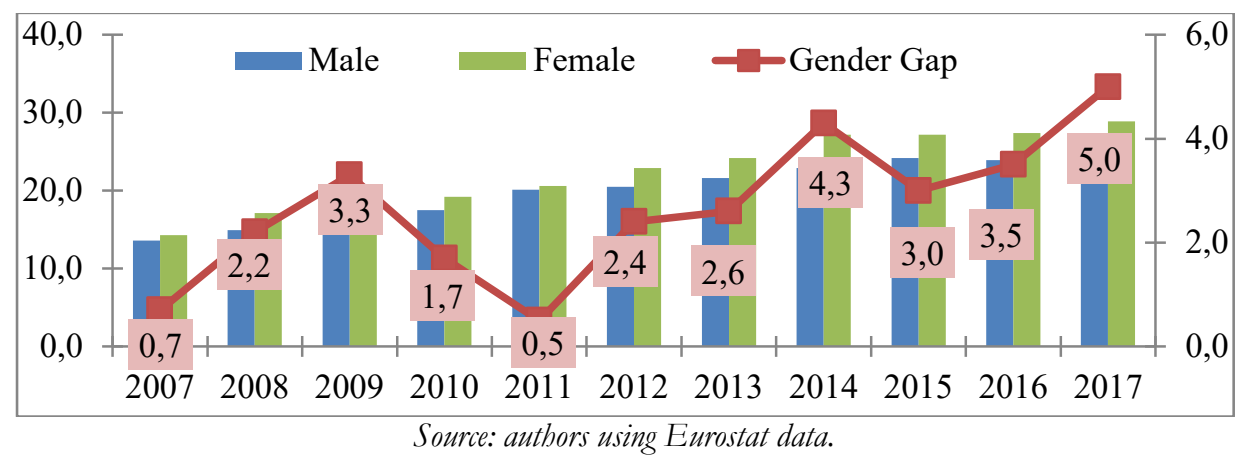

Figure no. 2. Gender gap regarding tertiary studies accomplished by Romanian people between 30 and 34 years, 2007-2017 (\%)

In order to get a broader view of completed studies of the female population, we have expanded data analysis on the entire population of Romania, aged 15 to 64 years. Figure no. 3 emphasize the distribution of the female population on the three studies levels, namely the higher degree (level 5-8), secondary and other than higher degree (level 3-4) and category of „non studies, primary studies or below the secondary degree” (level 0-2).

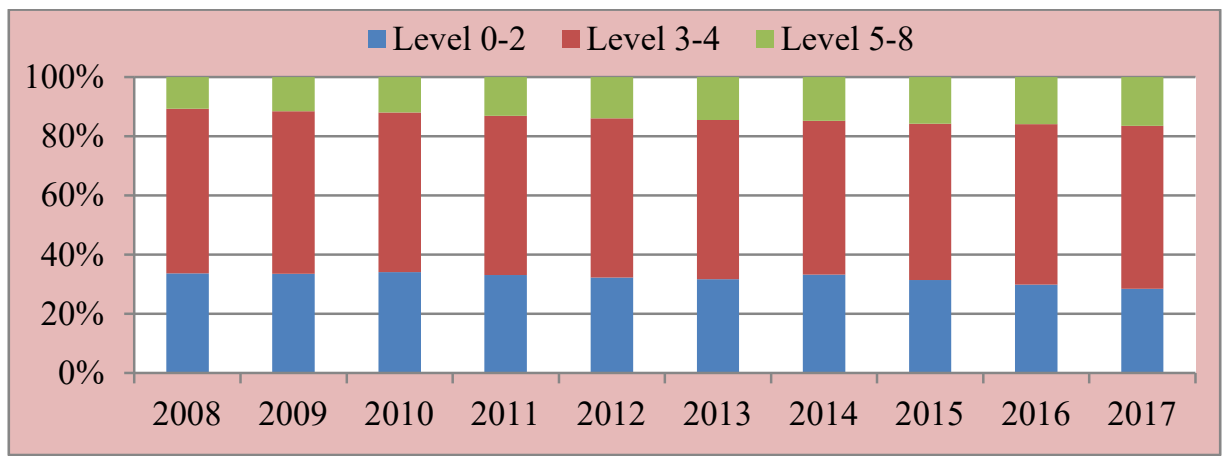

Source: authors using Eurostat data.

Figure no. 3. Structure of Romanian female population between 15 and 64 years, according to education level, 2008-2017 (\%) 
The share of women who completed higher degree is increasing steadily from $10.5 \%$ in 2008 to $16.5 \%$ in 2017 . The share of women with secondary or post-secondary studies is relatively constant, with little variation between 2008 and 2017 (from 55.6\% in 2008 to 55.1\% in 2017) and the share of population with an education level below the secondary degree has a significant decrease, from 33.75 in 2008 to $28.4 \%$ in 2017. It can be said therefore that it is a raise of education level of the female population from the 0-2 level to the 3-4 level (secondary studies) and then to the 5-8 level (university studies and above).Figure no. 4 shows the difference between male and female population, aged between 15 and 64 years old, on the three levels of education.

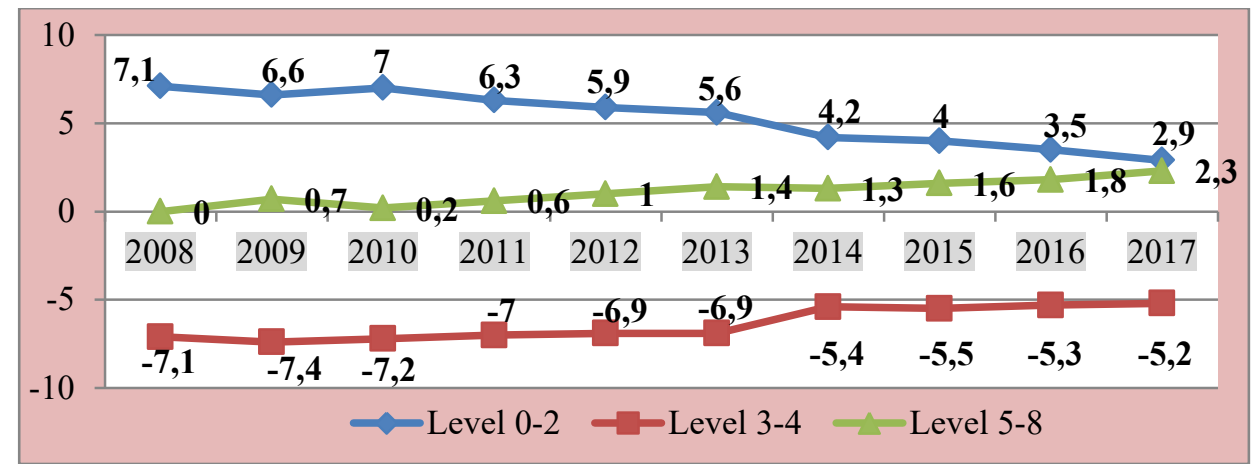

Source: authors using Eurostat data.

Figure no. 4. Gender gap of Romanian population between 15 and 64 years, according to education level, 2008-2017 (\%)

We note that the female population has a higher graduation rate than men for higher education, and the trend is increasing, but also for studies below the secondary level (level 0-2), where the trend is downward, however. Graduation rate of men surpasses that of women for the category of medium (secondary) studies, although the gap between the sexes is weakening.

\subsection{Romania Women's Participation in Lifelong Learning}

Lifelong learning is measured in EU for the population aged between 25 and 64 years, through a Eurostat survey who aims to establish the number of people who received education or training in the last 4 weeks preceding the survey. The indicator thus obtained does not include informal learning corresponding to self-learning. 
In UE28 the participation rate in education and training was $10.9 \%$ in 2017 (compared to its target of 15\%). Lower rates were recorded in several Member States, especially in Central and Eastern Europe, such as Hungary (6.2\%), Lithuania (5.9\%), Greece (4.5\%), Poland (4\%), Slovakia $(3.4 \%)$, and Croatia (2.3\%). But Romania ranks last in adult education, with a rate of only $1.1 \%$ in 2017, while the assumed objective for Romania is $10 \%$.

If we analyse the structure, by the two sexes of the population between 25 and 64, during the period from 2012 to 2017, we note, on the one hand, the low level of adult learning and the decreasing trend, and on the other hand, the tendency to reduce the disparities between the sexes in the context of generally weak interest for this type of education (figure no. 5).

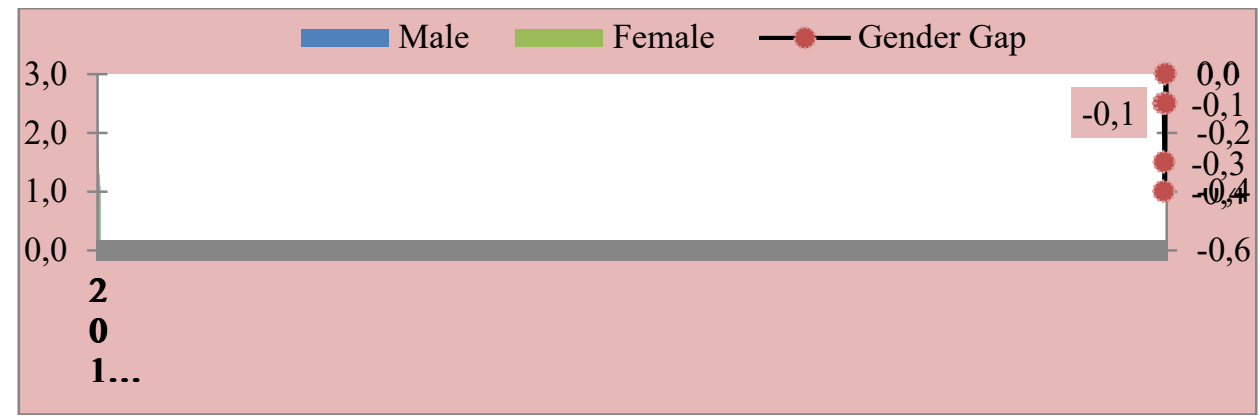

Source: authors using Eurostat data.

Figure no. 5. Participation of Romanian population between 25 and 64 years in adult learning, 2012-2017 (\%)

\subsection{Education of Roma population in Romania}

We also wanted to study the situation for Roma people in Romania in terms of access to education. In this case we had no access to primary statistical data, but only secondary data provided by reports on this population. One of these reports was prepared by the Decade of Roma Inclusion Secretariat Foundation in 2015 and shows the situation of the Roma by countries on several thematic areas including education. As regards Romania, the report shows a significant increase of Roma access to education in 2015 comparing to 2005, at all levels.

However the gap between Roma and the general population has increased for the category secondary level of education (in 2005, was $47 \%$ $6 \%=41 \%$ and it reached $56 \%-10 \%=46 \%$ in 2015), as well as for higher education (in 2005 was $7 \%$ and in 2015 reached 13\%). If the female Roma population, the proportion of women graduates is on each of the three levels, under the weight of the total population. 
Regarding adult education, a survey by the World Bank, UNDP and the EC in 2011 showed that non Roma women's participation in adult education and apprenticeship is 5 times higher than that of Roma women' participation, while for men participation was 3 times higher for those of non Roma community comparing to the men of Roma communities [4].

Table no. 1. Access to education of Roma population in Romania (2015 versus 2005) (\%)

\begin{tabular}{|l|c|c|c|c|c|c|}
\hline Year & \multicolumn{3}{|c|}{2015} & \multicolumn{3}{|c|}{2005} \\
\hline $\begin{array}{c}\text { Education } \\
\text { level }\end{array}$ & $\begin{array}{c}\text { Total } \\
\text { population } \\
\text { of } \\
\text { Romania }\end{array}$ & $\begin{array}{c}\text { Roma } \\
\text { population }\end{array}$ & $\begin{array}{c}\text { Roma } \\
\text { female }\end{array}$ & $\begin{array}{c}\text { Total } \\
\text { population } \\
\text { of } \\
\text { Romania }\end{array}$ & $\begin{array}{c}\text { Roma } \\
\text { population }\end{array}$ & $\begin{array}{c}\text { Roma } \\
\text { female }\end{array}$ \\
\hline $\begin{array}{c}\text { Pre- } \\
\text { school } \\
\text { education }\end{array}$ & $63 \%$ & $37 \%$ & $39 \%$ & --- & --- & -- \\
\hline $\begin{array}{c}\text { Primary } \\
\text { education }\end{array}$ & $97 \%$ & $80 \%$ & $77 \%$ & $94 \%$ & $66 \%$ & $60 \%$ \\
\hline $\begin{array}{c}\text { Secondary } \\
\text { education }\end{array}$ & $56 \%$ & $10 \%$ & $8 \%$ & $47 \%$ & $6 \%$ & $4 \%$ \\
\hline $\begin{array}{c}\text { Tertiary } \\
\text { education }\end{array}$ & $14 \%$ & $1 \%$ & $1 \%$ & $7 \%$ & $0 \%$ & $0 \%$ \\
\hline
\end{tabular}

Source: "Roma inclusion Index 2015", p. 57.

\section{Discussions}

Statistical data analysis allows us to make a comparison between the situation of Romania and other European countries or the EU average in terms of access to education and training in general and, in particular, the situation of the female population.

In terms of access to education and training in general, Romania has an unfavourable position compared with other MS, a situation which places it in the back of the field of EU countries for: a higher early school dropout of the population (18 and 24 years) is high (18.1\% in 2017 compared to 10\% in the UE28); a lower rate of young people (30 and 34 years) who have completed higher education (only $26.3 \%$ in 2017 compared to $34.9 \%$ in the UE28); the lowest percentage in the EU28 of people participating in adult training (1.1\% in 2017). The effects of low level of education are felt in the shortage of skilled labour and low labour competitiveness. By default, the rates of school dropout and the level of education and training by gender are worse than the European average, but also compared to most Member States. Among the sources of high dropout include many factors: economic, social, educational. In this context, it is noteworthy that the female population does not seem to be especially affected by early school leaving. 
But a special case is the Roma population where access to education is lower than the national average.

In the analysis of gender differences in education we noticed:

- early school dropout rate was higher in the male population in the range 18 to 24 years, between 2010 and 2015, while from 2016 is higher among women. Differences between the sexes are not significant, but more interesting is the difference compared with the trend in the EU where the dropout rate is higher among boys;

- the share of people between 30 and 34 years who have completed higher education was higher among women and the trend is increasing;

- by levels of education, the female population has a higher weight than the men in the categories "below secondary level" (trend decreasing) and also "university level" (growing trend);

- the rate of participation of the female population over 25 years adult learning is low and declining, the trend is similar for the two sexes.

According to statistics, the female population is not experiencing a negative situation in terms of access to education; the situation is quite similar to that of the male population. Romania's problem is thus rather increasing access to education in general for children and youth, but also adults, so that Romania should not deal last in terms of adult learning. Regarding education of Roma women, the situation is different, in this case observing differences compared with Roma male population as well as with female population to the national level. Thus, Roma women have a lower rate of participation in education than men of the same ethnicity, regardless of level of education but also in relation to the total female population share. We don't have statistical data, but it is possible that the high rate of school dropout in the female population in Romania in relation to the male population and leading to a gap different from that of the EU may be explained on account of the existing situation among Roma women.

The limits of our study consist in the lack of data on subpopulations in terms of access to different levels of education, the dropout rate or graduation rate (Roma women, the rural female population versus urban female population). Establishing quantitative statistics at national and institutional levels is a goal of the national strategy for higher education, the idea being appropriate in terms of the possibility to better understand the situation of the population and to improve decision-making process.

Improving the Romania situation should focus, on the one hand, by increasing access to education in general and, on the other hand, by supporting the categories for which access is lower than the national average, such as Roma and especially Roma female population. 
Regarding adult learning numerous deficiencies were identified at three levels (insufficient information between institutions, reduced incentives for participation in training and institutional capacity inadequate) [6]. National strategy for lifelong learning adopted in 2016 proposed a series of measures; of these, we consider particularly appropriate the financial incentives for companies or individuals (eg. adults who left school early, the unemployed, inactive or low skills persons) to participate in continuous training and to build partnerships with training providers, financial support for training providers to diversify the supply of training, involving technical and vocational schools and institutions of higher education, recognition of prior learning including competences acquired abroad [6]. Adult learning can be a solution for reducing disparities in education for Roma and especially Roma women.

\section{Conclusions}

The results obtained by analysis of statistical data shows that there aren't significant differences between women and men in access to education and the situation of women has improved during the period analyzed (2007-2017). However, there are significant differences in the case of the Roma population as a whole, and especially for Roma women population. For this category, although the access to education has improved it remains well below the national average at all levels of education (primary, secondary, tertiary), but also for adults learning.

Measures to improve access to education, in terms of the objectives assumed by Romania in education, require a complex intervention in order to ensure both institutional framework and adequate conditions to support disadvantaged groups such as Roma women.

\section{References}

[1] ANOSR. Fondul pentru bursele studenților se va acorda pentru întreaga durată a anului universitar; 2017. Available from: https://www.anostr.ro/fondulpentru-bursele-studentilor-se-va-acorda-pentru-intreaga-durata-a-anuluiuniversitar/ [Accessed 3rd February 2020].

[2] CE. Comunicare a Comisiei COM (2010) 2020 final, "Europa 2020. O strategie europeană pentru o creștere inteligentă, ecologică și favorabilă incluziunii”". Bruxelles; 2010.

[3] EC. Education and Training Monitor 2016 - Romania; 2016. EC, Eurostat Database. Available from: https://ec.europa.eu/eurostat/data/database [Accessed 3rd February 2020]. 
[4] Decade of Roma Inclusion Secretariat Foundation. Roma Inclusion Index 2015; September 2015.

[5] Strategia Naţională pentru Învățământ Terţiar (SNÎT) 2015-2020.

[6] Strategia Națională de Învățare pe tot Parcursul Vieții (SNÎPV) 2015-2020. 